\title{
Functional properties of Cornelian cherry (Cornus mas L.): a comprehensive review
}

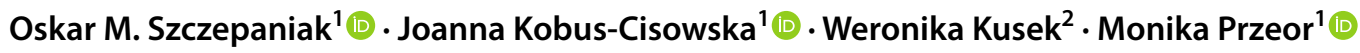

Received: 12 December 2018 / Accepted: 30 May 2019 / Published online: 22 June 2019

(c) The Author(s) 2019

\begin{abstract}
Cornus mas, also known as the Cornelian cherry, is a plant that grows in Eastern Europe and the Middle East. Its green leaves and reddish oval fruits are associated with many beneficial properties such as antioxidative and anti-inflammatory effects. These features are driven by the rich polyphenolic composition, with anthocyanins and iridoids in Cornelian cherry fruits as well as flavonoids and phenolic acids in leaves. The antioxidant behavior as well as the composition significantly depends on the cultivar of the plant and its genotype. The functional properties of Cornelian cherry have been recognized in many in vitro and toxicological studies. Cornus mas fruits and their extracts have been found to have significant antiatherogenic, anti-inflammatory, and neuroprotective effects. The beneficial effect of $C$. mas fruits as a food component has been determined in numerous papers focused on functional food. However, there is no information in existing literature about $C$. mas leaves in functional food applications. This paper presents the results of current studies including their synthesis to answer the question whether the Cornelian cherry exhibits positive properties due to its bioactive compound content.
\end{abstract}

Keywords Cornus mas $\cdot$ Polyphenols $\cdot$ Anthocyanins $\cdot$ Antioxidative activity $\cdot$ Functional foods

\section{Introduction}

The Cornelian cherry, also known as dogwood, is a plant that grows in the east and south regions of Europe and in West Asia. Cornelian cherry trees reach $7-8 \mathrm{~m}$ in height and can grow in temperate climate on drained soils [1,2]. Fruits are edible with an oval or pear-like shape and ranging in color from red to purple. The weight of the Cornelian cherry's fruit ranges from 2.09 to $9.17 \mathrm{~g}$, depending on

Oskar M. Szczepaniak

oskar.szczepaniak@up.ponan.pl

Joanna Kobus-Cisowska

joanna.kobus@up.poznan.pl

Weronika Kusek

wkusek@nmu.edu

Monika Przeor

monika.przeor@up.poznan.pl

1 Department of Gastronomical Sciences and Functional Foods, Poznan University of Life Sciences, ul. Wojska Polskiego 31, 60-624 Poznan, Poland

2 Earth, Environmental and Geographical Sciences Department, Northern Michigan University, 1401 Presque Isle Ave., Marquette, MI 49855-5301, USA the plant genotype and cultivation conditions [3, 4]. Fruit harvest yields 500-1000 kg per hectare in the case of wildgrowing plants, but in orchards the yield can increase even fivefold [5]. Klimenko states that one wild-growing bush of Cornelian cherry can yield $2.8-10 \mathrm{~kg}$ of fruit, whereas yield reaches $80 \mathrm{~kg}$ per bush for trees cultivated in an orchard [6]. The fruits are usually harvested when their peel color becomes very intense and the flavor develops to an acceptable limit [7]. Cornus mas is famous for being a rich source of vitamin $\mathrm{C}$ and polyphenols. Significant amounts of flavonoids, anthocyanins, and iridoids were identified in the fruits and leaves of the Cornelian cherry. These compounds are linked with intense radical scavenging potential and antitumour properties $[8,9]$. Cornus mas is also a traditional component of liquors, jams, comfitures and other fruit-based products [2]. Cornelian cherry has many regional cultivars which differ between each other in physical properties (i.e., shape, fruit color, etc.) as well as nutrient composition [10]. The Cornelian cherry is a recognized food ingredient in traditional cuisines of Poland, Czech Republic, Serbia, Romania, Turkey, and Iran [1, 2, 11-14]. In Poland and Ukraine, the tradition of growing and using the Cornelian cherry in cuisine was interrupted by post-World War II social and cultural changes which were a result of habitat erosion $[6,15]$. 
The phytochemicals present in Cornus mas L. have antiinflammatory and antiatherosclerotic properties in vivo; they can also protect cells against the neurogeneration process [16-18].

Recently, research into the potential application of Cornus mas has been conducted and expanded by numerous examples of novel functional food applications based on the Cornelian cherry's fruits extracts. Foods including extracts from the Cornelian cherry featured a higher antioxidative potential than their its standard equivalents; they were also accepted by consumers $[19,20]$.

The aim of this paper is to present recent information about the Cornelian cherry's nutrients, pro-health properties, and examples of its usage in functional food production.

\section{Sugar and mineral salt composition in Cornus mas L. fruits}

Cornelian cherry's fruit is rich in microelements such as copper, zinc, and manganese. Concentration values for these minerals in fresh fruit are estimated at 110-170, 260-350 and 2400-2900 $\mu \mathrm{g} / 100 \mathrm{~g}$, respectively [21]. The Cornelian cherry is also a valuable source of potassium-it contains over $3500 \mathrm{mg} / 100 \mathrm{~g}$ of fresh fruit, which means that $1 \mathrm{~g}$ of Cornus mas meets the full intake of potassium recommended by the WHO $[21,22]$. Similar results were provided by Gozlekci et al., noting that the potassium concentration in Cornelian cherry was cultivar deviated and the concentration value ranged $2780-3340 \mathrm{mg}$ per $100 \mathrm{~g}$ fw (fresh weight) [23]. Juice made from the Cornelian cherry was rich in calcium $(32.3 \mathrm{mg} / 100 \mathrm{ml})$ and micronutrients such as iron, zinc, and manganese [24].

The water concentration in fresh as well as in frozen Cornus mas fruit was three times higher than in dry fruit (327.53\% and $314.42 \%$, respectively) [25]. Polatoglu and Bese noted that the moisture content in fresh Cornelian cherry was about $75.4 \%$ [26].

The soluble solids content (SSC) ranged from 10.7 to $19.3 \%$ which significantly correlated with genotype variation [27]. Ercisli et al. [28] noted that this parameter ranges from 13.7 to $18.6 \%$, which is similar to those found by Vidrih et al. [27]. The SSC depends on the maturity of the fruit. According to Serce et al., SSC for blush cornelian cherries equals $12.2 \%$, while for mature, dark red fruit this value rises to $16.5 \%$ [7].

The reducing sugars content (RSC) in fresh fruit juice ranged from 8.64 to $15.24 \%$ [29] for five different Turkish genotypes. According to Yilmaz et al., RSC measured for Turkish Cornelian cherry was between 2.81 and $7.06 \%$ [3]. Serbian cultivars had similar RSC values (13.58-20.85\%), with the highest value represented by the cultivar that ripened the latest [30]. In Polish cultivars, the RSC value was between 9.08 and $14.70 \%$, while the total sugars content (TSC) was equal to $10.23-16.29 \%$. The poorest RSC and TSC values were found in the cv. Podolski, while cv. Szafer was the richest in sugars [15]. As opposed to the Serbian Cornelian cherries, the Polish equivalents were harvested at the same time, indicating that the significant sugar content variation is not based solely on differences in cultivation. Fructose and glucose were predominant among the reducing sugars (3.69 and 5.39\%, respectively) [31].

Dietary fiber composition is also dependent on the cultivar variation. Nawirska-Olszańska et al. observed that neutral dietary fiber and acidic dietary fiber differed between tested cultivars between $10.7-16.1 \mathrm{~g} / 100 \mathrm{~g}$ fresh weight (fw) and 7.6-12.2 g/100 g fw, respectively [32]. In the same paper, the authors found that the Polish Cornelian cherry cultivars contained pectins, hemicelluloses, and lignins (contents appr. 1.0-1.6 g/100 g fw, 2.3-4.5 g/100 g, and $3.3-8.5 \mathrm{~g} / 100 \mathrm{~g} \mathrm{fw}$, respectively). According to Tarko et al., the total dietary fiber amount in Cornus mas (over 1.53\%) is significantly lower than the values noted for apples or bananas [31]. The dietary fiber and polysaccharides content is dependent on the growing conditions, as is the case for other phytocompounds [32,33].

\section{Phytocompounds composition in Cornelian cherry fruits}

In the Cornelian cherry, the presence of an abundance of polyphenolic compounds was confirmed. According to De Biaggi et al., the total polyphenol amount reached $37 \%$ of all bioactive compounds described in the paper (i.e., polyphenols, monoterpenes, organic acids, and vitamin C) measured in fresh weight of fruits [9]. The usually detected organic molecules in Cornus mas can be divided into five structural groups: anthocyanins, iridoids, phenolic acids, flavonoids, and tannins [34]. The total amount of polyphenols ranged from 219.08 to $976.51 \mathrm{mg} / 100 \mathrm{~g}$ of fresh weight, due to differences in the extraction process and cultivars used in research $[12,34,35]$. Rop et al. stated that the total amount of polyphenolic content was cultivar dependent. In their study, the total polyphenolic content was the lowest for the Devin cultivar (261 mg gallic acid equivalent (GAE)/100 $\mathrm{g} \mathrm{fw}$ ), and the Vydubieckii had the highest concentration of polyphenol (811 mg GAE/100 g fw) [2]. Kucharska et al. presented research following the same method, but their data showed that the richest in polyphenols was cv. Szafer $(464 \mathrm{mg} / 100 \mathrm{~g})$ and the poorest was cv. Juliusz (262 mg/100 g) [15]. These proceedings are consistent with Yilmaz et al.'s paper, in which they showed how the polyphenol concentration was genetically related [3]. Polyphenol content can be linked to the amount of juice and peel color [30, 36, 37]. Cultivar Szafer possessed the most 
intense purple color of all cultivars, and it was also the richest in TPC among the cultivars tested by Kucharska et al. In the study by Adamenko et al. [38], an analogous relationship could be noticed in meads prepared with different Cornus mas juices with different colors ranging from amber yellow to red. Another question addressed by the researchers was the percentage of stone mass in total fruit mass. The bigger the stone mass, the more decreased are the results for TPC expressed in GAE per fresh mass ratio. Milenkovic-Andjelkovic et al. indicated in their study that the polyphenol content slightly depended on the cultivation conditions which differ from year to year $(90 \mathrm{mg} \mathrm{GAE} / \mathrm{g}$ dry weight (dw) in 1 year and $91 \mathrm{mg} \mathrm{GAE} / \mathrm{g} \mathrm{dw}$ in the following one) [4].

The prevalent phytocompounds in fruits are catechinscyclic organic molecules classified as flavonoids-as well as phenolic acids [9]. In a study performed by De Biagii et al., the four major ingredients were: ellagic acid, epicatechin, catechin and chlorogenic acid (Table 1). The less significant cinnamic acid derivatives were ferulic acid, coumaric acid, caffeic acid and vescalagin (appr. 2, 4, 1 and $5 \mathrm{mg} / 100 \mathrm{~g} \mathrm{fw}$, respectively) [9]. Moldovan et al. proved that the most prevalent components were quercetin-3-Oglucuronide (471 mg/100 g fw), kaempferol-3-O-galactoside (366.88 mg/100 g fw) and ellagic acid (Table 1) [12]. Moreover, their findings concerning polyphenolic acid and catechin composition are inconsistent with research by De Biaggi et al. (Table 1). The variance can be explained by the differences in analytical procedures, concerning the extraction process and HPLC analysis conditions. The effect of environmental factors such as insolation or amount of rainfall on phytochemical content in plant tissues can be significant $[39,40]$. According to Pawłowska et al., the total amount of quercetin derivatives in fruits was nearly fourfold higher than in the data published by Molodovan et al. (Table 1). In the study by Pawlowska et al., the quercetin derivatives were identified as quercetin 3-O-xyloside, quercetin 3-O-rhamnoside, quercetin 3-O-rutinoside, quercetin 3-O-galactoside, quercetin 3-O-glucoside and quercetin
3-O-glucuronide, where the last one predominated (nearly $700 \mathrm{mg} / 100 \mathrm{~g}$ ) [41]. In Moldovan et al.'s paper, only one quercetin analogue was tested [12].

Anthocyanins are specific compounds with a pro-health impact found in functional foods, and are also included in Cornelian cherry fruits. They are relatively unstable and reactive molecules and its color depends on $\mathrm{pH}$, temperature, light exposure, and metal presence [42]. They play a dual role as natural pigments and bioactive compounds. These pigments are easily degraded in standard food manufacturing conditions as well as during storage, which results in significant changes in their color and nutritional value [43, 44].

Among the anthocyanins present in Cornus mas, the prevalent constituents are 3-O-galactosides of delphinidin $(162 \mathrm{mg} / 100 \mathrm{~g})$, cyanidin $(166 \mathrm{mg} / 100 \mathrm{~g})$ and pelargonidin; cyanidin-3-O-galactoside $(3.82 \mathrm{mg} / 100 \mathrm{~g} \mathrm{fw})$ as well as pelargonidin $3-\mathrm{O}$-glucoside $(58.62 \mathrm{mg} / 100 \mathrm{~g} \mathrm{fw})$ and 3-O-rutinoside (33.8 mg/100 g fw) (Fig. 1) [12, 34]. Anthocyanins are compounds with antioxidant behavior confirmed in many studies [45-47]. Moreover, anthocyanins can create complexes with DNA strands and therefore protect genetic material against oxidative stress [48]. Unfortunately, the bioavailability of anthocyanins by humans is relatively low [49, 50]. In Cornus mas, sakuratenin (a naringenin methylated form) and aromadendrin were also detected [51].

A broader study of anthocyanins present in different $C$. mas cultivars was performed by Kucharska et al. The cultivate $C$ zarny possessed the highest amount of anthocyanins among all the tested varieties $(341.18 \mathrm{mg} / 100 \mathrm{~g} \mathrm{fw})$, whereas the cv. Yantarnyi had no anthocyanins at all [52]. In the same study, the authors concluded that the prevalent compounds were galactosides of pelargonidin and cyanidin. The differences in anthocyanins and organic acid concentrations between the tested cultivars and genotypes were $\mathrm{pH}$ related. The $\mathrm{pH}$ value of 2 which is natural for Cornelian cherry juice caused a hypochromic effect on its UV-Vis spectra, whereas a decrease of the $\mathrm{pH}$ to 4.0 generated the bathochromic effect [53].
Table 1 Catechins and phenolic acids present in Cornus mas fruits expressed in $\mathrm{mg} / 100 \mathrm{~g} \mathrm{fw}$ $[9,12,41]$

\begin{tabular}{llcl}
\hline References & De Biaggi et al. [9] & Moldovan et al. [12] & $\begin{array}{l}\text { Paw- } \\
\text { lowska } \\
\text { et al. [41] }\end{array}$ \\
\hline Ellagic acid & $23.56 \pm 0.67$ & $187.91 \pm 5.87$ & $\mathrm{Ne}$ \\
Epicatechin & $21.74 \pm 0.99$ & $66.89 \pm 2.88$ & $\mathrm{Ne}$ \\
Catechin & $14.38 \pm 0.20$ & $37.06 \pm 1.73$ & $\mathrm{Ne}$ \\
Chlorogenic acid & $11.27 \pm 0.04$ & $32.76 \pm 1.24$ & $\mathrm{Ne}$ \\
Caffeic acid & $0.66 \pm 0.00$ & $27.12 \pm 1.02$ & $\mathrm{Ne}$ \\
Kaempferol-3-O-galactoside & $\mathrm{Ne}$ & $366.88 \pm 7.82$ & 413 \\
Total amount of quercetin & $\mathrm{Nd}$ & $471.01 \pm 9.15$ & 1679 \\
\hline
\end{tabular}

$N=3$

$\mathrm{Ne}$ not examined in study, $\mathrm{Nd}$ not detected 
<smiles>OCC1O[C@H](O)C(O)[C@H](O)C1Oc1cc2c(O)cc(O)cc2[o+]c1-c1cc(O)c(O)c(O)c1</smiles>

\section{delfinidin-3-0-galactoside}<smiles>OCC1OC(O)[C@H](O)C(O)[C@H]1Oc1cc2c(O)cc(O)cc2[o+]c1-c1ccc(O)c(O)c1</smiles>

cyanidin-3-0-galactoside<smiles>OCC1OC(O)[C@H](O)[C@H](O)C1Oc1cc2c(O)cc(O)cc2[o+]c1-c1ccc(O)cc1</smiles>

pelargonidin-3-0-galactoside

pelargonidin-3-0-glucoside<smiles>COc1cc(-c2[o+]c3cc(O)cc(O)c3cc2OC2C(CO)OC(O)[C@H](O)C2O)ccc1O</smiles>

peonidin-3-0-glucoside<smiles>C[C@H]1O[C@H](OC[C@H]2O[C@H](Oc3cc4c(O)cc(O)cc4[o+]c3-c3ccc(O)cc3)[C@@H](O)[C@H](O)[C@H]2O)[C@H](O)[C@@H](O)[C@H]1O</smiles>

pelargonidin-3-0-rutinoside

Fig. 1 Chemical structures of anthocyanins present in Cornelian cherry [12, 34] 


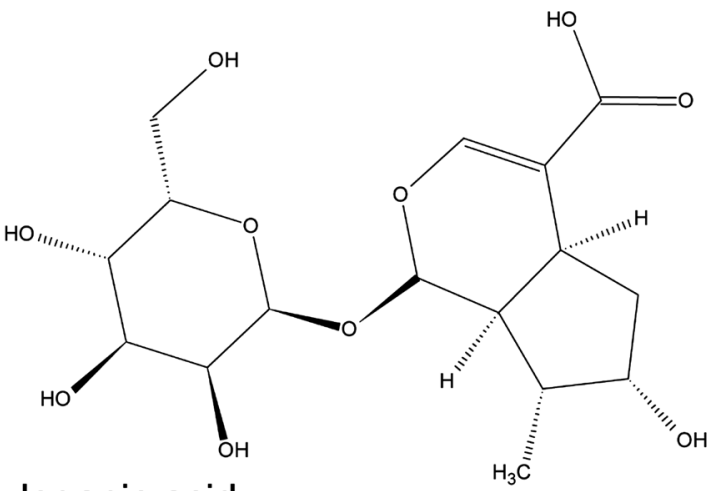

loganic acid

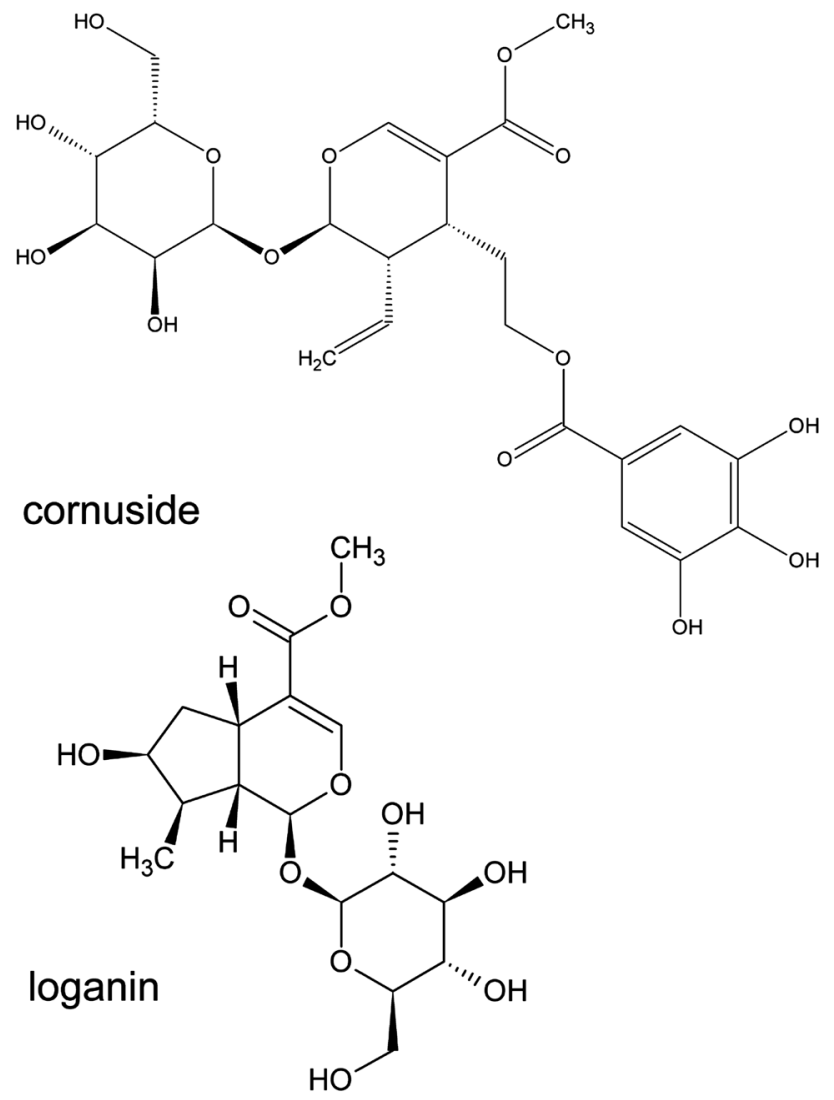

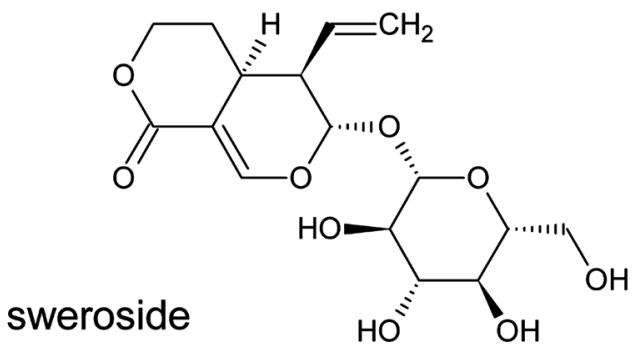

Fig. 2 The chemical structures of loganic acid, loganin, sweroside and cornuside $[52,56]$
Besides anthocyanins, the Cornelian cherry also contains iridoids-organic molecules with anti-inflammatory and antioxidative properties [34]. In Cornus mas, two iridoids have been detected-cornuside and loganic acid (Fig. 2), and their concentrations in ripe fruits range from $8.22-36.25 \mathrm{mg} / 100 \mathrm{~g}$ fw for the first to $81.53-461.08 \mathrm{mg} / 100 \mathrm{~g}$ fw for the latter, according to cited research $[8,38,52]$. This can be related to the growing conditions and stress factors affecting the plant, including harsh climate and insect attacks $[54,55]$. Iridoids are the compounds which protect plants against consumption by insects [55]. An assay performed by Deng et al. demonstrated that loganin and sweroside are also present in Cornelian cherry fruits (Fig. 2). In addition to iridoids, tartaric acid and malic acid at concentrations 1.5-1.6-fold higher than cornuside were detected in Cornelian cherry [56].

The differences in the amounts of iridoids are linked to the analysis method, cultivar used, and cultivation practice [52].

To conclude the works cited in this paragraph, we concur that qualitative characteristics and quantitative content of Cornelian cherry fruits depend on many factors. Authors usually highlight the impact of cultivar, cultivation conditions, plant growth conditions and the extraction process on fruit content. The analytical method is often discussed as well. However, in its entirety, the existing research indicates that polyphenols are the predominant compounds in the Cornelian cherry, mainly composed of phenolic acids (i.e., benzoic acid derivatives and cinnamic acid derivatives) and flavonols, particularly quercetin derivatives.

\section{Ascorbic acid content}

Vitamin $\mathrm{C}$ as an antioxidant plays a protective role in cardiovascular diseases. Moreover, many studies show that its reactions and conversions help to stimulate biological processes [57]. Ascorbic acid is vital for the proper functioning of the immune system, as it takes part in the immunomodulatory processes and stimulates the interferon synthesis. Vitamin $\mathrm{C}$ is a cofactor of numerous enzymes containing ferrous ions, i.e., hydroxylases and oxygenases. The presence of the ascorbic acid is vital for keeping ferrous ions reduced [58].

The concentration of vitamin $\mathrm{C}$ in Cornelian cherry has been widely examined $[1,2,12,34]$. Its concentration ranges from over 29 to nearly $300 \mathrm{mg} / 100 \mathrm{~g}$ fw (Table 2). According to Yilmaz et al., the concentration of ascorbic acid in Cornus mas was twofold higher than in oranges [3]. Pantelidis et al. confirmed that and noted that vitamin $\mathrm{C}$ content in Cornelian cherry was meaningfully higher than in kiwi and strawberries (29-80 mg/100 mg fw and $31 \mathrm{mg} / 100 \mathrm{mg}$ fw, respectively) [59]. 
Table 2 Concentration of ascorbic acid in Cornus mas fruits according to cited sources

\begin{tabular}{lllllll}
\hline References & $\begin{array}{l}\text { Vidrih et al. [27] } \\
\text { HPLC }\end{array}$ & $\begin{array}{l}\text { Kostecka et al. [60] } \\
\text { Spectroscopic }\end{array}$ & $\begin{array}{l}\text { Kostecka et al. [60] } \\
\text { Iodometric }\end{array}$ & $\begin{array}{l}\text { Pantelidis et al. [59] } \\
\text { Reflectometry }\end{array}$ & $\begin{array}{l}\text { Aghdam et al. [61] } \\
\text { Spectroscopic }\end{array}$ & $\begin{array}{l}\text { Hassanpour et al. [62] } \\
\text { Spectroscopic }\end{array}$ \\
\hline Ascorbic acid & $29-86$ & $55-83$ & $153-237$ & $103 \pm 13$ & 85 & $183-300$ \\
\hline
\end{tabular}

Concentrations given in $\mathrm{mg}$ per $100 \mathrm{~g}$ fw [27, 59-61]

${ }^{\mathrm{a}} N=3$

The deviation in ascorbic acid concentration can be explained by two independent factors. First, the composition of vitamin $\mathrm{C}$ is related to the genotype and cultivar of analyzed Cornelian cherry fruit [27]. In Iranian Cornelian cherry's fruit, the concentration of ascorbic acid ranged between 183 and $300 \mathrm{mg} / 100 \mathrm{~g}$, whereas for the Czech cultivars grown in the moderate, more humid and colder climate, the ascorbic acid concentration ranged between 175 and $277 \mathrm{mg} / 100 \mathrm{~g}[2,62]$. For the varieties grown in Poland, this range varied between 34 and $75 \mathrm{mg} / 100 \mathrm{~g}$ [60]. Second, the method of detection can be the source of the variation. In the research done by Kostecka et al., it was shown how the method affected the ascorbic acid content [60]. For the same genotype of $C$. mas, the results can be threefold higher when the iodometric and spectroscopic methods are compared (Table 2).

The addition of $\mathrm{CaCl}_{2}$ to the fruits after harvesting led to a 1.5-fold or even twofold higher concentration of ascorbic acid in fruit extracts [61]. Similar results were reached after salicylic acid treatment-the rise in vitamin $C$ value was over $30 \%$ after $2 \mathrm{mM}$ of salicylic acid treatment [13]. The addition of $\mathrm{CaCl}_{2}$ to tomatoes after harvesting also caused a significant rise in AA level and TSS level [63]. According to Abbasi et al., the higher presence of calcium in fruit flesh, after such a treatment, can inhibit the enzymatic processes in flesh which causes the degradation of vitamin C [63].

Sun drying of the Cornelian cherry fruit is a good way of nonthermal processing of this product, but it causes a drop in vitamin $\mathrm{C}$ to over 50\%. According to Polatoglu and Bese, this decrease is caused by the light-induced degradation of AA [26]. Similar results were achieved by drying with the use of a food dryer at $60{ }^{\circ} \mathrm{C}$ (appr. $45 \%$ ), as well as by freezing Cornus mas fruits (appr. 58\%) [25].

As indicated in the paragraphs above, the content of vitamin $\mathrm{C}$ depends on various factors, including harvest period, cultivar deviation, cultivation conditions as well as storing and post-harvest treatments. Cornelian cherry as a fruit rich in AA can have beneficial effects related to its presence.

\section{Phytocompounds composition in Cornus mas leaves}

Cornelian cherry leaves have been recognized as a natural remedy for centuries. Their properties are linked with the plant's secondary metabolites like polyphenols and tannins. In a study performed by Badalica-Petrescu et al., the presence of 15 polyphenolic compounds was confirmed (Fig. 3). The total polyphenol amount was about $105 \mathrm{mg} \mathrm{GAE} / 100 \mathrm{ml}$ of extract which is threefold higher than the total polyphenol concentration in Crataegus monogyna evaluated in the same study [14]. According to Forman et al., the total polyphenol concentration in water extract is estimated to be approximately $8.3 \%$ [64]. In their second study, Forman et al. noted that the concentration of flavonoids present in Cornus mas leaves $(0.21 \%)$ is lower than for Cornus kousa, another edible Cornaceae species [65].

Celep et al. determined that in a $80 \%(\mathrm{v} / \mathrm{v})$ methanolic extract of Cornelian cherry leaves, the amount of polyphenols reaches $343 \mathrm{mg}$ GAE$/ \mathrm{g}$ dw and the total flavonoid content equals $73 \mathrm{mg} \mathrm{QE}$ (quercetin equivalent)/100 $\mathrm{g} \mathrm{dw}$ [66]. However, Milenković-Andjleković et al. [4] gained values threefold lower-113-117 mg/100 g dw, which is similar to Badalica-Petrescu et al.'s results. The concentration values for individual compounds are not equal (Table 3 ). This can be explained by differences in research methodology and variations in the approach to data presentation.

The leaves of Cornus mas contain at least 27 organic acids, and the most prevalent are oxalic, palmitic, 2,4-heptadienoic, citric, linoleic and malic acids [67].

\section{Antioxidative effect of Cornelian cherry}

The ability of radical scavenging is connected with the rich polyphenolic compounds composition [34]. Cornus mas fruit extracts have an antioxidant potential which is poorer than that of other fruits rich in vitamin $\mathrm{C}$. The results depend on the cultivation condition, which was observed by Milenkovic-Andjelkovic et al. In their study, $100 \mathrm{ml}$ of dogwood fruit extract can scavenge $94-109 \mathrm{mg}$ of dissolved DPPH radicals [4].

The DPPH (diphenylpicrylcarbazyl) radical inhibition test is a quick and inexpensive spectrophotometric method of 
<smiles>C[C@@H]1O[C@@H](Oc2cc(O)c3c(=O)c(O[C@@H]4O[C@H](CO)[C@@H](O)[C@H](O)[C@H]4O)c(-c4ccc(O)c(O)c4)oc3c2)[C@H](O)[C@@H](O)[C@H]1O</smiles>

quercetin 3-0-galactoside, 7-0-rhamnoside<smiles>Oc1ccc([C@@H]2Oc3cc(O)c(O)cc3C[C@H]2O)cc1O</smiles><smiles>O=C(/C=C/c1ccc(O)c(O)c1)O[C@H]1C[C@@](O)(C(=O)O)C[C@H](O)[C@H]1O</smiles><smiles>[R]Oc1ccc(/C=C/C(=O)O)cc1O[R]</smiles>

\section{caffeic acid derivatives}<smiles>O=C(O)[C@H]1O[C@@H](Oc2c(-c3ccc(O)cc3)oc3cc(O)cc(O)c3c2=O)[C@H](O)[C@@H](O)[C@@H]1O</smiles>

kaempferol 3-glucuronide<smiles>O=C(O)/C=C/c1ccccc1O[C@@H]1O[C@H](CO)[C@@H](O)[C@H](O)[C@H]1O</smiles>

p-coumaric acid sugar derivative<smiles>[R]Oc1ccc(/C=C/C(=O)O)cc1</smiles>

p-coumaric acid derivative<smiles>O=C(O)[C@H]1O[C@@H](Oc2c(-c3ccc(O)c(O)c3)oc3cc(O)cc(O)c3c2=O)[C@H](O)[C@@H](O)[C@@H]1O</smiles>

quercetin 3-glucuronide<smiles>COc1cc(-c2oc3cc(O[C@@H]4O[C@H](C)[C@@H](O)[C@H](O)[C@H]4O)cc(O)c3c(=O)c2O)ccc1O</smiles>

rhamnetin 7-rhamnoside

Fig. 3 Polyphenolic compounds detected in Cornus mas leaves extracts [14] 
Table 3 Phytocompounds present in Cornelian cherry leaves and their concentration values expressed in $\mathrm{mg} / 100 \mathrm{ml}$. According to cited positions $[4,14]$

\begin{tabular}{lll}
\hline Compound & $\begin{array}{l}\text { Badalica-Petrescu et al. [14] } \\
{[\mathrm{mg} / 100 \mathrm{ml}]}\end{array}$ & $\begin{array}{l}\text { Milenkovic-Andjelkovic } \\
\text { et al. [4] [mg/100 g dw] }\end{array}$ \\
\hline Caffeic acid derivatives & 6 & $\mathrm{Ne}$ \\
Quercetin derivatives & 8 & $928-937$ \\
Isorhamnetin-7-rhamnoside & 1 & $\mathrm{Ne}$ \\
Kaempferol-3-glucuronide & 3 & $\mathrm{Ne}$ \\
Chlorogenic acid & 12 & $28-33$ \\
Epicatechin & 14 & $407-415$ \\
Catechin & $\mathrm{Ne}$ & $222-228$ \\
Kaempferol-3-glucoside & $\mathrm{Ne}$ & $427-437$ \\
$o$-Coumaric acid hexoside & 9 & $\mathrm{Ne}$ \\
$p$-Coumaric acid derivative & 14 & $\mathrm{Ne}$ \\
Vitexin-2'-O-rhamnoside & 60 & $\mathrm{Ne}$ \\
Vitexin-4'-O-rhamnoside & 5 & $\mathrm{Ne}$ \\
Rutin & $\mathrm{Ne}$ & $609-611$ \\
Gallic acid & $\mathrm{Ne}$ & $37-41$ \\
Ellagic acid & $\mathrm{Ne}$ & $255-262$ \\
\hline
\end{tabular}

$\mathrm{Ne}$ not examined detection of antioxidative agents in the analyzed samples. The method is based on the addition of samples with antioxidants to a solution of DPPH, afterwards the changes in the absorbance of the DPPH solution are measured.

Hassanpour et al. stated that the efficiency of DPPH radicals' scavenging depends on the total polyphenolic concentration, total flavonoids, and ascorbic acid content (Pearson coefficients: $0.54,0.60$ and 0.47 , respectively) [62]. In the cited study, fruit extracts scavenged DPPH radicals at levels varying from 38.98 to $77.6 \%$. The statistical relation between radical scavenging and polyphenolic composition has been additionally proven in many studies $[1,4,59]$.

The antioxidative properties are also correlated with the possibility of ferrous ions $\left(\mathrm{Fe}^{3+}\right)$ reduction. According to Biaggi et al., the Cornelian cherry extract can reduce $20.41 \mu \mathrm{mol} \mathrm{Fe} e^{2+}$ per gram of solution [9]. The ferric-reducing antioxidant properties method (FRAP) is regularly treated as a common spectrophotometric assay. The reactive $\mathrm{Fe}^{3+}$ ions are reduced by the antioxidative agents to $\mathrm{Fe}^{2+}$ at the presence of TPTZ (2,4,6-tripyridyl-s-triazine), which affects the absorbance of the solution at $\lambda=593 \mathrm{~nm}$. A study conducted by Yilmaz et al. presents a significant range of FRAP values, in which the minimum is 73 and the maximum reaches $114 \mu \mathrm{mol}$ AA (ascorbic acid) equivalent per gram of dw [3]. Pantelidis et al. confirms that the FRAP value is approximately $84 \mu \mathrm{mol}$ AA/g dw [59]. However, Popovic et al. present a different range for this parameter, which is probably caused by a data presence question. In their study, the ferric-reducing antioxidant power ranges from 2 to $65 \mu \mathrm{mol} / \mathrm{ml} \mathrm{Fe}^{2+}$ [68].

Studies focusing on Cornelian cherry leaves show that their radical scavenging activity is lower than for fruits. The DPPH radical scavenging capacity ranges between 165 and $790 \mathrm{mg} / \mathrm{g}$ (Table 3). Leja et al. stated that radical activity against DPPH equals $94.54 \%$, which is similar to the values for Rosa canina (95.08\%) and Crataegus monogyna $(91.70 \%)$ described in the same study [35].

\section{Anti-inflammatory effect of Cornelian cherry}

Cornelian cherry leaves present significant inhibitory properties against the aldose reductase - an enzyme the overexpression of which is connected with many inflammation processes, cancers as well as diabetes. In an in vivo study, water leaves extract halved the activity of the aldose reductase at a concentration of about $1 \mu \mathrm{g} / \mathrm{ml}$, which is threefold less than pure quercetin (nearly $3 \mu \mathrm{g} / \mathrm{ml}$ ) [69].

In a broader research done by Świerczewska et al., methanolic extracts of Cornelian cherry fruits halved the lipase activity at a concentration of $48 \mu \mathrm{g} / \mathrm{ml}$, while for the aqueous and ethanolic extracts, this parameter was lower ( -34 and $15 \mu \mathrm{g} / \mathrm{ml}$, respectively [70]). Furthermore, the 
intake of powdered C. mas by rabbits with an elevated blood cholesterol content led to a significant drop in fibrinogen levels, compared to a drop achieved after a $10 \mathrm{mg}$ lovastatin therapy [71]. Moreover, leaf extracts halved the radionuclei-induced lipid peroxidation ratio [72]. Similar results were obtained for a medical study in which Cornus mas extracts seemed to improve the lipid profile and reduce vascular inflammation [73]. In a complex in vivo research, the presence of anthocyanins from Cornelian cherry boosted the expression of PPAR $\gamma$ (193\% growth) and PPAR $\alpha$ (85.2\% growth) in the liver [8]. The peroxisome proliferator-activated receptors (PPAR) are a group of cellular receptors which are responsible for the energy equilibrium, glucose homeostasis, lipid metabolism and oxidation [74]. The PPAR $\gamma$ receptor is responsible for the lipid transformation in cells and is the main regulator of the adipogenesis process [75].

According to Świerczewska et al., Cornelian cherry fruits may reduce the rate of $\alpha$-amylase activity. From all of the examined extracts, the methanolic one was the most efficient and its $\mathrm{IC}_{50}$ value (the concentration which halves the activity rate) reached $79.0 \mu \mathrm{g} / \mathrm{ml}$ [70]. Moreover, a study done by Jayaprakasam et al. proved that the intake of Cornelian cherry inhibits glucose intolerance. According to the authors of this paper, the obesity and sugar intolerance is reduced by anthocyanins, the concentration of which is significant in C. mas [76].

The intake of Cornus mas by hypercholesterolemic rabbits improved the level of glutathione in their aortas and positively affected their intimae thickness [16]. According to Sozański et al., dimethylarginine species, i.e., asymmetric dimethylarginine and symmetric dimethylarginine (ADMA and SDMA) are known as cardiovascular disorder markers. The authors described that the intake of a lyophilisate of Cornelian cherry fruits resulted in a drop in the dimethylarginine concentration in serum, while the concentration of L-arginine increased, which provided a highly beneficial effect [16]. The protective effect can be also delivered by cornuside itself, as it inhibits the biological synthesis of nitric (NO) radical and tumor necrosis factor alpha (TNF$\alpha$ ), mediated by lipopolysaccharides (LPS) [77, 78]. The authors of the referenced studies tested the impact of Cornus officinalis, another species of Cornaceae. However, the biological properties of Cornus mas and C. officinalis are similar [34] [34].

Cornus mas fruit extracts present a positive anti-parasitological effect. The intake of fruit extracts caused the proliferation of lymphocytes in parasite organisms in vivo [79]. According to Piekarska et al., the results were granted by the beneficial composition of fruit extracts, which are rich in iridoids and anthocyanins. The extracts from both the Cornelian cherry fruits and leaves significantly inhibit the growth of pathogenic bacteria and yeast. In a study performed by
Milenkovic-Andjelkovic et al., the presence of leaf extracts inhibits the growth of Bacillus cereus and Clostridium perfringens in a ratio equal to $2 / 3$ of the tetracycline activity and achieves almost the same activity in Staphylococcus aureus growth inhibition [4].

Results provided by Szumny et al. show that Cornelian cherry extracts can help in intraocular pressure decrease, which is linked with a high concentration of iridoids, especially loganic acid, in extracts [80].

Cornelian cherry features neuroprotective effects as well. In an in vivo study, the intake of lyophilized Cornelian cherry boosted the catalase activity in rats' brains [18]. Catalase is an enzyme which cleaves the peroxides made during the oxidative stress. Moreover, an addition of the Cornelian cherry was linked to a higher activity of paraoxonase-an enzyme which stops the lipoproteins oxidation process [18]. However, Celep et al. discovered that methanolic extracts from $C$. mas leaves can decrease the activity of catalase and raise the glutathione (GSH) peroxidase activity both in blood and in liver of rats in vitro [66]. When the livers of rats had been previously treated with $\mathrm{CCl}_{4}$, the intake of leaves extracts caused a rise in the activity of both catalase and GSH peroxidase proportional to the intake value [66]. Alavian et al. noted that intake of Cornelian cherry by rats inhibits the liver peroxidation process and decreases the amount of proteins in serum [81].

Leaf extracts obtained in Savikin et al.'s study featured meaningful anticancer potential. In the mentioned study, leaf extracts decreased the growth rate of HeLa cells [82]. Similar results were reached for fruits studied by Bahman et al. They observed a significant apoptosis of four carcinogenic cells lines (SKOV3, MCF-7, PC-3 and A549) [83]. According to Leskovac et al., leaf extracts possess radioprotective properties, i.e., they help in cell regeneration after radioactive dosage intake [72].

To conclude, literature contains numerous proceedings describing the positive properties of the Cornelian cherry. These properties are relevant to both the leaves and fruits of the Cornelian cherry. It was shown that the biological activity is related to a group of phytocompounds present in the plants' anatomical parts. Phytocompounds present in leaves (i.e., polyphenols, irydoids, anthocyanins) possess positive anti-inflammatory and anti-cancer properties. Cornelian cherry extracts also positively affect the lipid profile of blood in terms of triglycerides and fibrinogen levels, and reduce the predispositions for cardiovascular diseases. The antidiabetic activity and antibacterial effect against Grampositive microorganisms were demonstrated as well.

Compounds present in fruits (including anthocyanins, iridoids, and polyphenols) affect the energy balance, glucose and lipid metabolism, and participate in the adipogenesis process. Cornus mas fruits contain compounds which inhibit the $\alpha$-amylase activity and reduce dimethylarginine concentration in serum. Fruit extracts can help in reducing 
intraocular pressure, they act as neuroprotective agents and inhibit the liver peroxidation process. Moreover, they have positive antibacterial, antifungal, and antiparasitic activities.

\section{Functional food products with Cornelian cherry}

The flavor of the Cornelian cherry is specific, cherry-like, and considered as sour or sweet and sour, depending on the tasted cultivar or genotype [33, 84]. The shelf life of ripened fruit is rather short. The storage of harvested Cornelian cherry fruits for a month in cool conditions causes a decay of over $70 \%$ of the stored fruits [85]. The modified atmosphere packaging (MAP) of Cornus mas fruits can prolong the freshness of the product and protect it against decay $[85,86]$. The MAP packaging that was based on an increase in the concentration of oxygen and carbon dioxide in the package to $60 \%$ and $20 \%$, respectively, led to a significant improvement in the results of visual assessment of stored fruits and inhibited vitamin $\mathrm{C}$ degradation and titratable acidity nearly by half [86].

Cornus mas used to be a traditional component of liquors, jams, and fruit preserves. The Cornelian cherry is generally recognized as a main ingredient of the Dereniówka liquor in Poland and Drenja in Balkan countries [87]. Tesevic et al. [87] analyzed the volatile compounds present in
Drenja, which are responsible for the fragrance bouquet and discovered that the predominant compounds were 2- and 3-methyl-1-butanol (analyzed together in the study at conc. $207 \mathrm{mg} / 100 \mathrm{ml})$ and ethyl acetate $(198 \mathrm{mg} / 100 \mathrm{ml})$, whereas Tarko et al. [31] observed that Cornelian cherry wine contained isoamyl alcohols $(44 \mathrm{mg} / 100 \mathrm{ml})$ and isobutanol fraction $(14 \mathrm{mg} / 100 \mathrm{ml})$. Ethyl acetate concentration was poorer (4 mg/100 ml). Sokół-Łętowska et al. analyzed the compositions of a few versions of Dereniówka, which differed in sugar concentration and storage conditions (Table 4). Their liquors were prepared from fresh fruit mixed with $65 \%$ ethanol at a mass ratio of $1: 1$ and macerated for 21 days at ambient temperature without light access [88]. According to Dragoni et al., alcohol promotes a higher absorption of quercetin in wine [89]. A similar property should be noted for Cornelian cherry liquor. The rich polyphenolic composition and interesting sweet and sour flavor could draw the attention of functional food producers to the Cornelian cherry. Fruit freshness and maturity are important, because the polyphenolic content in raw material and its antioxidant profile determines the observed levels in ready products [38, 85, 88]. Other studies described the properties of meads made with different cultivars of the Cornelian cherry and various fermentation yeasts used [38]. For juice obtained from cv. Podolski, the finished product mead had a higher polyphenolic concentration as well as improved antiradical activity than the Koralovyi juice (Table 4). These parameters

Table 4 The reference data on the total polyphenol amount and radical scavenging activities for the model food samples enriched with Cornus mas fruits [11, 20, 38, 88, 96-99]

\begin{tabular}{|c|c|c|c|c|}
\hline Product & $\begin{array}{l}\text { Total polyphenol amount } \\
{[\mathrm{mg} \text { GAE/100 g] or }[\mathrm{mg}} \\
\text { GAE/100 ml] }\end{array}$ & $\begin{array}{l}\text { DPPH scavenging activity } \\
{[\mu \mathrm{mol} \mathrm{TE} / \mathrm{g}] \text { or }[\mu \mathrm{mol} \mathrm{TE} /} \\
\mathrm{ml}]\end{array}$ & $\begin{array}{l}\text { ABTS scavenging activity } \\
{[\mu \mathrm{mol} \mathrm{TE} / \mathrm{g}] \text { or }[\mu \mathrm{mol} \mathrm{TE} /} \\
\mathrm{ml}]\end{array}$ & References \\
\hline $\begin{array}{l}\text { Mead with cv. Podolski } \\
\text { juice }\end{array}$ & $77-90$ & 6 & 6 & Adamenko et al. [38] \\
\hline $\begin{array}{l}\text { Mead with cv. Koralovyi } \\
\text { juice }\end{array}$ & $42-61$ & 5 & $6-7$ & \\
\hline Jam $50 \%$, conc. & 1 & 2 & 4 & Nawirska et al. [20] \\
\hline Jam $30 \%$ conc. & 2 & 2 & 4 & \\
\hline Liquor sweetened & 25 & $\mathrm{Nd}$ & $\mathrm{Ne}$ & Sokół-Łętowska et al. [88] \\
\hline Liquor unsweetened & 26 & $\mathrm{Nd}$ & $\mathrm{Ne}$ & \\
\hline Yogurt & 72 & 217 & $\mathrm{Ne}$ & Barat and Ozcan [96] \\
\hline 'False olives' cv. Jurek & $87-141$ & $10-13$ & $11-16$ & Kucharska et al. [11] \\
\hline 'False olives' cv. Juliusz & $91-133$ & $10-13$ & $12-15$ & \\
\hline 'False olives' & $143-316$ & $12-22$ & $15-32$ & Czyżowska et al. [97] \\
\hline $\begin{array}{l}\text { Dessert } \\
\text { w/Cornus mas juice }\end{array}$ & 4 & 137 & $\mathrm{Ne}$ & Ivanova et al. [98] \\
\hline $\begin{array}{l}\text { Dessert w/Cornus mas } \\
\text { juice encapsulated }\end{array}$ & 5 & 358 & $\mathrm{Ne}$ & \\
\hline Cornelian cherry pulp & 365 & 27 & $\mathrm{Ne}$ & Kucharska et al. [99] \\
\hline $\begin{array}{l}\text { Cornelian cherry pulp with } \\
\text { chokeberry } 20 \% \text { conc. }\end{array}$ & 767 & 47 & $\mathrm{Ne}$ & \\
\hline
\end{tabular}

$\mathrm{Nd}$ not detected, $\mathrm{Ne}$ not examined in study, $T E$ trolox equivalent 
were significantly higher than for mead aged without Cornelian cherry (i.e., total polyphenol number appr. $2 \mathrm{mg}$ $\mathrm{GAE} / 100 \mathrm{ml}$ ) [38].

In Nawirska et al.'s study, Cornelian cherry was used as an ingredient of jam [20]. The Cornelian cherry concentration differed between two samples, which resulted in different polyphenolic concentrations and antioxidant properties (Table 4). At the preparation stage of functional food production, polyphenols present in raw plants can be removed by elution from plant tissues into an aqueous medium $[90,91]$. The thermal treatment of fruits and vegetables can increase free polyphenol concentrations due to the breakdown of plant cells, in which the polyphenols are present [92]. On the other hand, strong interactions between polyphenolic compounds and the cell wall limits limit their extraction, which is positive in terms of the discussed processing losses. During food manufacture and storage, plant polyphenols are converted into various derivatives, mainly due to their sensitivity to heat and the physicochemical environment $[90,91]$. These conversions can have an impact on their final antioxidative properties [91]. Additionally, the sugar presence in jam positively affects the flavonoid content in jam after prolonged storage [93]. Results show that the preparation of food rich in anthocyanins causes significant losses of monomeric anthocyanins and a drop in their antioxidant capacity. Anthocyanins are subject to degradation in storage in all thermally treated products-losses may reach up to $40 \%$ [94]. Anthocyanins present in Cornus mas may be subject to conversions during processes required to prepare functional foods. Physical processes affecting the stability of anthocyanins include washing operations, blanching, canning, and cooking [94, 95].

Barat and Ozcan used Cornelian cherry juice as an additive to yogurt. The addition of Cornelian cherry juice resulted in almost zero syneresis in yogurt $(1.40 \mathrm{ml} / 100 \mathrm{ml})$ as well as the lowest $\mathrm{pH}$ value (3.79) from all tested samples in the paper [96]. The presence of juice resulted in a greater total amount of bacteria in yogurt and had a positive effect on their survivability [96]. Czyżowska et al. conducted a similar experiment in which the Cornelian cherry fruits were fermented by lactic fermentation species such as Lactobacillus lactis. They stated that after fermentation, Cornelian cherry fruits were enriched in the microflora at an amount higher [4.73-5.86 log colony-forming units (CFU)] than at the inoculation stage (4.00 log CFU) [97]. The polyphenol content and the antiradical potential in yogurt enriched in Cornus mas juice seem to be very significant and in contrast to the food products mentioned earlier (Table 4). The root cause can be traced to microflora metabolism, which hydrolyzes the oligo- and monosaccharic residues from the aglycone, which results in a higher absorbance of polyphenols and affects the polyphenolic content in the food matrix [100]. In Czyżowska et al.'s study, the quantitative determination of iridoids in false olives indicated loganic acid (34.76-130.23 mg/100 g) and cornuside $(2.15-15.69 \mathrm{mg} / 100 \mathrm{~g})$ amounts close to that in ripe, fresh fruits [97].

Similar implications can be drawn from Topdas et al.'s study in which they examined how different percentages of Cornelian cherry addition affected the sensory and antioxidant properties, as well as the concentrations of examined polyphenols [19]. Similar to the study by Barat and Ozcan, the addition of Cornelian cherry pulp resulted in a decrease in the $\mathrm{pH}$ value, from 6.7 for the control to even 5.3 for the sample with the highest Cornus mas additive [19]. Additionally, the fruit pulp concentration was positively related to the total phenolic content, the sample's general accessibility and flavor, although it had a negative effect on the ice cream's sweetness [19]. If the encapsulation of juice was engaged, the total amount of polyphenols and antioxidant properties soared, probably because of the better homogenization of the food matrix (Table 4). Cerit et al. used Cornelian cherry fruits as an ingredient in white chocolate, which resulted in 2.5-fold higher DPPH radical scavenging and ferric-reducing activity in comparison to white chocolate without this ingredient [101]. These observations show that Cornelian cherry fruits can be used as a functional additive to products traditionally considered as 'junk food' and its presence does not diminish consumer acceptability. Unfortunately, this conclusion cannot be applied to products enriched in Cornelian cherry fruits. Salejda et al. state that the low $\mathrm{pH}$ value of Cornelian cherry juice (over 2.4 value) negatively affects the protein structure of burgers during preparation and storage [102].

Fermented unripe Cornelian cherries were served in South-East Poland in ancient times [11]. Thanks to their color and taste, they were used instead of olives as apperitives and additives to salads. Recently, the subject of the so-called 'Polish olives' had its revival thanks to the research papers which highlighted their beneficial properties [11, 97]. In a study performed by Kucharska et al., the total polyphenolic content and antioxidant properties of the Cornelian cherry are slightly different due to the cultivars used in the fermentation process (Table 4). However, the values concerning DPPH scavenging are about fivefold higher for both samples than the parameter measured for 'real' olives (2.1-2.7 $\mu \mathrm{M} \mathrm{TE} / \mathrm{g})$. For the cationic radical ABTS [2,2'-azino-bis(3-ethylbenzothiazoline-6-sulphonic acid)], this ratio is smaller (C. mas:olives: about 3:1), whereas there is no significant difference in the total amount of polyphenols (for olives 72-134 mg/100 g) [11].

The addition of other fruits to the $C$. mas pulp can sometimes result in a positive, synergistic effect. Kucharska et al. tested how the addition of different berries (chokeberry, strawberry, and raspberry) promotes the antioxidant properties and polyphenol concentration in Cornelian cherry 
fruit pulp [99]. The findings indicate that a $20 \%$ addition of chokeberry to the Cornelian cherry pulp doubles the total polyphenol amount and causes a growth of $75 \%$ in DPPH radical scavenging activity (Table 4). The addition of Cornelian cherry to pekmez-Turkish fruit-based syrup, resulted in a better sensory profile, smaller viscosity, and higher concentrations of minerals such as potassium, calcium, iron, and zinc [103].

Another interesting application is fruit vinegar production. Kawa-Rygielska et al. manufactured vinegar from three different cultivars of Cornus mas and two different fermentation methods, which resulted in different total phenolic values and antioxidant activity [104]. They fermented pressed Cornelian cherry juices using either one-stage spontaneous fermentation at $25^{\circ} \mathrm{C}$, or a two-stage process: initial alcoholic fermentation by Saccharomyces bayanus and then spontaneous vinegar fermentation at $25{ }^{\circ} \mathrm{C}$. Similarly to the paper describing the Dereniówka (traditional Cornelian cherry liqueur) [88], the total polyphenolic amount expressed in mg GAE per $100 \mathrm{ml}$ was the highest for the Podolski cultivar, the most reddish one [104]. That indicates a correlation between the concentration of polyphenols and fruit juice color, which was also described in similar papers $[2,3,100,105]$. Regarding the antioxidant scavenging, the results of the cited study were not affected by the variety used for vinegar production, which can be caused by fact the Yantarnyi cultivar (characterized by the lowest total amount of polyphenols) may contain other antioxidative compounds not detected in the study.

Unfortunately, in light of this publication, we could not find works describing the usage of Cornelian cherry leaves in model food or as an ingredient in functional food production. Probably, the application of Cornus mas leaves has not yet been explored. The addition of plant leaves to bread is a successful method of providing it with functional properties such as decreasing acrylamide levels in the ready product, growth of polyphenol content and antioxidant properties, as well as the improvement of bread texture [106, 107]. Leaves added to beverages can significantly raise the antioxidant potential and affect the rheological properties of ready product $[108,109]$. Due to the multidirectional effect of ingredients present in Cornelian cherry, the application of Cornus mas leaves as a supplement additive would warrant plenty of positive impacts on the human organism. The generally known goal of supplement intake and functional product production is to improve the health of consumers. Prohealth ingredients of functional food products and supplements can include mineral components (i.e., calcium, iron, magnesium), pro- and prebiotics, fiber, essential unsaturated fatty acids (n-3 and n-6), soy protein, isoflavones (i.e., genistein) and others $[110,111]$. Dietary supplements regularly contain preparations of leaves, which are either not normally consumed in the diet, or they are not functional food ingredients $[112,113]$. One example of popular leaf-based supplement ingredients are mulberry leaves. White mulberry (Morus alba) is famous for its fruits, while its leaves contain phytocompounds with a high antidiabetic effect. DNJ $(1,5$ dideoxy-1,5-imino-D-sorbitol), an alkaloid present in leaves, inhibits the activity of $\alpha$-glycosidases [114-116]. Another dietary supplement component which is widely recognized as rich source of bioactive compounds, are Ginkgo biloba leaves [117, 118]. Ginkgo leaves contain substances belonging to flavonoid, terpene and proanthocyanidin groups which thanks to their proportions in the leaves provides beneficial health effects [118]. These ingredients help to improve the blood flow in the brain, due to their protective effect against the peroxidation of cerebral lipids. They also reduce the risk of edema [119]. Currently, research is being conducted on other biological ingredients which could improve the memorization process $[120,121]$. To conclude, the results presented above demonstrate that the properties of Cornelian cherry compounds and the current trends in the application of plant leaves as ingredients of dietary supplements result in the purposefulness of research into the application of Cornus mas leaves in dietary and medicinal practice.

\section{Conclusion}

The Cornelian cherry has significant potential for further research. It is characterized by a high content of iridoids and anthocyanins. The high content of these compounds is related to the significant antioxidant potential of both fruit and leaf extracts. The Cornelian cherry extracts were reported to be potential anti-inflammatory agents both in in vitro and in vivo studies, also in situations when the Cornelian cherry was processed to obtain functional food or traditional meals. Application of fruits to functional food production has been repeatedly described.

The application of Cornelian cherry leaves in functional food may be a separately interesting focus of research and development. Leaves also contain many ingredients beneficial for improving and maintaining health. However, the majority of papers in existing literature have been devoted to the Cornelian cherry fruits and their potential of serving as functional food additives. Cornus mas leaves and their properties have been solely considered in studies based on model matrices. In existing literature, there are proceedings indicating the possibility of using leaves as raw material to obtain important biologically active compounds. The current state of knowledge about the properties of the Cornelian cherry can be valuable for both food technologists and pharmacists. 
Author contributions Idea for the article-OMS; literature search and data analysis-JK-C and OMS; manuscript draft-JK-C, WK, MP and OMS; work revision-WK.

\section{Compliance with ethical standards}

Conflict of interest We declare that we have no conflicts of interest.

Compliance with ethics requirements This article does not contain any studies with human participants or animals performed by any of the authors.

Open Access This article is distributed under the terms of the Creative Commons Attribution 4.0 International License (http://creativeco mmons.org/licenses/by/4.0/), which permits unrestricted use, distribution, and reproduction in any medium, provided you give appropriate credit to the original author(s) and the source, provide a link to the Creative Commons license, and indicate if changes were made.

\section{References}

1. Ersoy N, Bagci Y, Gok V (2011) Antioxidant properties of 12 cornelian cherry fruit types (Cornus mas L.) selected from Turkey. Sci Res Essays 6:98-102. https://doi.org/10.5897/SRE10 .740

2. Rop O, Mlcek J, Kramarova D, Jurikova T (2010) Selected cultivars of cornelian cherry (Cornus mas L.) as a new food source for human nutrition. Afr J Biotechnol 9:1205-1210. https://doi. org/10.5897/AJB10.1722

3. Yilmaz KU, Ercisli S, Zengin Y, Sengul M, Kafkas EY (2009) Preliminary characterisation of cornelian cherry (Cornus mas L.) genotypes for their physico-chemical properties. Food Chem 114:408-412. https://doi.org/10.1016/j.foodchem.2008.09.055

4. Milenkovic-Andjelkovic A, Andjelkovic M, Radovanovic A, Radovanovic B, Nikolic V (2015) Phenol composition, DPPH radical scavenging and antimicrobial activity of cornelian cherry (Cornus mas) fruit and leaf extracts. Hem Ind 69:331-337. https ://doi.org/10.2298/HEMIND140216046M

5. Mamedov N, Craker LE (2004) Cornelian cherry: a prospective source for phytomedicine. Acta Hortic 629:83-86. https://doi. org/10.17660/actahortic.2004.629.10

6. Klimienko S (2004) The cornelian cherry (Cornus mas L.): collection, preservation, and utilizationof genetic resources. J Fruit Ornam Plant Res 12:93-98

7. Gunduz K, Saracoglu O, Ozgen M, Serce S (2013) Antioxidant, physical and chemical characteristics of cornelian cherry fruits (Cornus mas L.) at different stages of ripeness. Acta Sci Pol Hortorum Cultus 12:12

8. Sozański T, Kucharska AZ, Rapak A, Szumny D, Trocha M, Merwid-Ląd A, Dzimira S, Piasecki T, Piórecki N, Magdalan J, Szeląg A (2016) Iridoid-loganic acid versus anthocyanins from the Cornus mas fruits (cornelian cherry): common and different effects on diet-induced atherosclerosis, PPARs expression and inflammation. Atherosclerosis 254:151-160. https://doi. org/10.1016/j.atherosclerosis.2016.10.001

9. De Biaggi M, Donno D, Mellano MG, Riondato I, Rakotoniaina EN, Beccaro GL (2018) Cornus mas (L.) fruit as a potential source of natural health-promoting compounds: physico-chemical characterisation of bioactive components. Plant Foods Hum Nutr 73:89-94. https://doi.org/10.1007/s11130-018-0663-4
10. Cornescu F-C, Cosmulescu SN (2017) Morphological and biochemical characteristics of fruits of different cornelian cherry (Cornus mas L.) genotypes from spontaneous flora. Not Sci Biol 9:577. https://doi.org/10.15835/nsb9410161

11. Kucharska AZ, Piórecki N, Sokół-Łętowska A, Żarowska B (2011) Characteristics of chemical composition and antioxidant properties of cornelian cherry fruit fermented in brine. Zesz Probl Postępów Nauk Rol 566:125-133

12. Moldovan B, Filip A, Clichici S, Suharoschi R, Bolfa P, David L (2016) Antioxidant activity of Cornelian cherry (Cornus mas L.) fruits extract and the in vivo evaluation of its anti-inflammatory effects. J Funct Foods 26:77-87. https://doi.org/10.1016/j. jff.2016.07.004

13. Dokhanieh AY, Aghdam MS, Fard JR, Hassanpour H (2013) Postharvest salicylic acid treatment enhances antioxidant potential of cornelian cherry fruit. Sci Hortic (Amsterdam) 154:31-36. https://doi.org/10.1016/j.scienta.2013.01.025

14. Badalica-Petrescu M, Dragan S, Ranga F, Fetea F, Socaciu C (2014) Comparative HPLC-DAD-ESI(+)MS fingerprint and quantification of phenolic and flavonoid composition of aqueous leaf extracts of Cornus mas and Crataegus monogyna, in relation to their cardiotonic potential. Not Bot Horti Agrobot Cluj-Napoca 42:9-18. https://doi.org/10.15835/nbha4219270

15. Kucharska AZ, Sokół-Łętowska A, Piórecki N (2011) Morphological, physical \& chemical, and antioxidant profiles of polish varieties of cornelian cherry fruit (Cornus mas L.). Żywność Nauk Technol Jakość 3:78-89

16. Sozański T, Kucharska AZ, Szumny D, Magdalan J, Merwid-Ląd A, Nowak B, Piórecki N, Dzimira S, Jodkowska A, Szeląg A, Trocha M (2017) Cornelian cherry consumption increases the L-arginine/ADMA ratio, lowers ADMA and SDMA levels in the plasma, and enhances the aorta glutathione level in rabbits fed a high-cholesterol diet. J Funct Foods 34:189-196. https://doi. org/10.1016/j.jff.2017.04.028

17. Sozański T, Kucharska AZ, Szumny A, Magdalan J, Bielska K, Merwid-Ląd A, Woźniak A, Dzimira S, Piórecki N, Trocha M (2014) The protective effect of the Cornus mas fruits (cornelian cherry) on hypertriglyceridemia and atherosclerosis through PPAR $\alpha$ activation in hypercholesterolemic rabbits. Phytomedicine 21:1774-1784. https://doi.org/10.1016/j.phyme d.2014.09.005

18. Francik R, Kryczyk J, Kros̈niak M, Berköz M M, Sanocka I, Francik S (2014) The neuroprotective effect of Cornus mas on brain tissue of wistar rats. Sci World J. https://doi. org/10.1155/2014/847368

19. Topdaş EF, İçeriği CV, Özellikleri D (2017) The antioxidant activity, vitamin $\mathrm{C}$ contents, physical, chemical and sensory properties of ice cream supplemented with cornelian cherry (Cornus mas L.) Paste Kızılcık (Cornus mas L.) Ezmesi İlaveli Dondurmanın Antioksidan. Kafkas Univ Vet Fakulltesi Derg 23:691-697. https://doi.org/10.9775/kvfd.2016.17298

20. Nawirska-Olszańska A, Kucharska A, Sokół-Łętowska A, Biesiada A (2010) Quality assessment of pumpkin jams enriched with japanese quince, cornelian cherry and strawberries. Zywn Nauk Technol Jakosc 1:40-48

21. Dokoupil L, Řezníček V (2012) Production and use of the Cornelian cherry-Cornus mas L. Acta Univ Agric Silvic Mendelianae Brun 60:49-58. https://doi.org/10.11118/actaun201260080 049

22. World Health Organisation (2012) Guideline: potassium intake for adults and children. World Health Organisation, Geneva

23. Gozlekci S, Esringu A, Ercisli S, Eyduran SP, Akin M, Bozovic D, Sagbas HI (2017) Mineral content of cornelian cherry (Cornus mas L.) fruits. Oxid Commun 40:301-308 
24. Krośniak M, Gąstoł M, Szałkowski M, Zagrodzki P, Derwisz M (2010) Cornelian cherry (Cornus mas L.) juices as a source of minerals in human diet. J Toxicol Environ Heal Part A 73:11551158. https://doi.org/10.1080/15287394.2010.491408

25. Rosu C, Zenovia O, Truta E, Todirascu-Ciornea E, Manzu C, Zamfirache M (2011) Nutritional value of Rosa spp. L. and Cornus mas L. fruits, as affected by storage conditions. Analele Stiint ale Univ „Alexandru Ioan Cuza” Sect Genet si Biol Mol 12:147-155

26. Polatoğlu B, Beşe AV (2017) Sun drying of cornelian Cherry fruits (Cornus mas L.) sun drying of cornelian cherry fruits (Cornus mas L.). Erzincan Univ J Sci Technol 10:68-77. https://doi. org/10.18185/erzifbed.289008

27. Vidrih R, Čejić Ž, Hribar J (2012) Content of certain food components in flesh and stones of the cornelian cherry (Cornus mas L.) genotypes. Croat J Food Sci Technol 4:64-70

28. Ercisli S, Yilmaz SO, Gadze J, Hadziabulic S, Aliman J (2011) Some fruit characteristics of cornelian cherries (Cornus mas L.). Not Bot Horti Agrobot Cluj-Napoca 39:255-259. https:// doi.org/10.15835/nbha3915875

29. Sengul M, Eser Z, Ercisli S (2014) Chemical properties and antioxidant capacity of cornelian cherry genotypes in Coruh Valley of Turkey. Acta Sci Pol Hortorum Cultus 13:73-82

30. Bijelić SM, Golosin BR, Ninić Todorović JI, Cerović SB, Popović BM (2011) Physicochemical fruit characteristics of cornelian cherry (Cornusmas L.) genotypes from Serbia. HortScience 46:849-853

31. Tarko T, Duda-Chodak A, Satora P, Sroka P, Pogoń P, Machalica J (2014) Chaenomeles japonica, Cornus mas, Morus nigra fruits characteristics and their processing potential. J Food Sci Technol 51:3934-3941. https://doi.org/10.1007/s13197-013-0963-5

32. Nawirska-Olszańska A, Kucharska AZ, Sokół-Łętowska A (2010) Frakcje włókna pokarmowego w owocach derenia właściwego (Cornus mas L.). Żywność Nauk Technol Jakość 2:95-103

33. Ercisli S, Orhan E, Esitken A, Yildirim N, Agar G (2008) Relationships among some cornelian cherry genotypes (Cornus mas L.) based on RAPD analysis. Genet Resour Crop Evol 55:613618. https://doi.org/10.1007/s10722-007-9266-x

34. Czerwińska ME, Melzig MF (2018) Officinalis—analogies and differences of two medicinal plants traditionally used. Front Pharmacol 9:1-28. https://doi.org/10.3389/fphar.2018.00894

35. Leja M, Mareczek A, Nanaszko B (2007) Antioxidant properties of fruits of certain wild tree and bush species. Rocz Akad Rol w Pozn 383:327-331

36. Cosmulescu SN, Trandafir I, Cornescu F (2018) Antioxidant capacity, total phenols, total flavonoids and colour component of cornelian cherry (Cornus mas L.) wild genotypes. Not Bot Horti Agrobot Cluj-Napoca 47:390. https://doi.org/10.15835/ nbha47111375

37. Demir F, Kalyoncu IH (2003) Some nutritional, pomological and physical properties of Cornelian cherry (Cornus mas L.). J Food Eng 60:335-341. https://doi.org/10.1016/S0260-8774(03)00056 $-6$

38. Adamenko K, Kawa-Rygielska J, Kucharska A, Piórecki N (2018) Characteristics of biologically active compounds in Cornelian cherry meads. Molecules 23:2024. https://doi.org/10.3390/molec ules 23082024

39. Choi HG, Moon BY, Kang NJ, Kwon JK, Bekhzod K, Park KS, Lee SY (2014) Yield loss and quality degradation of strawberry fruits cultivated under the deficient insolation conditions by shading. Hortic Environ Biotechnol 55:263-270. https://doi. org/10.1007/s13580-014-0039-0

40. Mendez-Costabel MP, Wilkinson KL, Bastian SEP, Jordans C, McCarthy M, Ford CM, Dokoozlian N (2014) Effect of winter rainfall on yield components and fruit green aromas of Vitis vinifera L. cv. Merlot in California. Aust J Grape Wine Res 20:100-110. https://doi.org/10.1111/ajgw.12060

41. Pawlowska AM, Camangi F, Braca A (2010) Quali-quantitative analysis of flavonoids of Cornus mas L. (Cornaceae) fruits. Food Chem 119:1257-1261. https://doi.org/10.1016/j.foodc hem.2009.07.063

42. Li D, Zhang X, Xu Y, Li L, Aghdam MS, Luo Z (2019) Effect of exogenous sucrose on anthocyanin synthesis in postharvest strawberry fruit. Food Chem 289:112-120. https://doi. org/10.1016/j.foodchem.2019.03.042

43. Sadilova E, Carle R, Stintzing FC (2007) Thermal degradation of anthocyanins and its impact on color and in wfroantioxidant capacity. Mol Nutr Food Res 51:1461-1471. https://doi. org/10.1002/mnfr.200700179

44. Hatier J-HB, Gould KS (2009) Anthocyanin function in vegetative organ. In: Gould K, Davies KM, Winefield C (eds) Anthocyanins biosynthesis, functions, and applications. Springer, Berlin, pp 7-9. https://doi.org/10.1007/978-0387-77335-3_1

45. Kong J-M, Chia L-S, Goh N-K, Chia T-F, Brouillard R (2003) Analysis and biological activities of anthocyanins. Phytopchemistry 64:923-933. https://doi.org/10.1016/S0031-9422(03)00438 $-2$

46. Miguel MG (2011) Anthocyanins: antioxidant and/or anti-inflammatory activities. J Appl Pharm Sci 01:7-15

47. Kähkönen MP, Heinonen M (2003) Antioxidant activity of anthocyanins and their aglycons. J Agric Food Chem 51:628-633. https://doi.org/10.1021/jf025551i

48. Sarma AD, Sharma R (1999) Anthocyanin-DNA copigmentation complex: mutual protection against oxidative damage. Phytochemistry 52:1313-1318. https://doi.org/10.1016/S0031 -9422(99)00427-6

49. Mazza G, Kay CD, Cottrell T, Holub BJ (2002) Absorption of anthocyanins from blueberries and serum antioxidant status in human subjects. J Agric Food Chem 50:7731-7737. https://doi. org/10.1021/jf0206901

50. McDougall GJ, Dobson P, Smith P, Blake A, Stewart D (2005) Assessing potential bioavailability of raspberry anthocyanins using an in vitro digestion system. J Agric Food Chem 53:58965904. https://doi.org/10.1021/jf050131p

51. Rudrapaul P, Kyriakopoulos AM, De UC, Zoumpourlis V, Dinda B (2015) New flavonoids from the fruits of Cornus mas, Cornaceae. Phytochem Lett 11:292-295. https://doi.org/10.1016/j. phytol.2015.01.011

52. Kucharska AZ, Szumny A, Sokól-Letowska A, Piórecki N, Klymenko SV (2015) Iridoids and anthocyanins in cornelian cherry (Cornus mas L.) cultivars. J Food Compos Anal 40:95-102. https ://doi.org/10.1016/j.jfca.2014.12.016

53. Babaloo F, Jamei R (2018) Anthocyanin pigment stability of Cornus mas-Macrocarpa under treatment with $\mathrm{pH}$ and some organic acids. Food Sci Nutr 6:168-173. https://doi.org/10.1002/ fsn3.542

54. Wang DH, Du F, Liu HY, Liang ZS (2011) Drought stress increases iridoid glycosides biosynthesis in the roots of Scrophularia ningpoensis seedlings. J Med Plants Res 4:2691-2699. https://doi.org/10.5897/JMPR09.338

55. Dyer L, Bowers M, Dyer LA, Bowers MD (1996) The importance of sequestered iridoid glycosides as a defense against an ant predator. J Chem Ecol 22:1527-1539

56. Deng S, West BJ, Jensen CJ (2013) UPLC-TOF-MS characterization and identification of bioactive iridoids in Cornus mas fruit. J Anal Methods Chem. https://doi.org/10.1155/2013/710972

57. Oliveira KRHM, dos Anjos LM, Araújo APS, Luz WL, Kauffmann N, Braga DV, da Conceição Fonseca Passos A, de Moraes SAS, de Jesus Oliveira Batista E, Herculano AM (2019) Ascorbic acid prevents chloroquine-induced toxicity in inner glial 
cells. Toxicol In Vitro 56:150-155. https://doi.org/10.1016/j. tiv.2019.01.008

58. Smirnoff N (2018) Ascorbic acid metabolism and functions: a comparison of plants and mammals. Free Radic Biol Med 122:116-129. https://doi.org/10.1016/j.freeradbio med.2018.03.033

59. Pantelidis GE, Vasilakakis M, Manganaris GA, Diamantidis G (2007) Antioxidant capacity, phenol, anthocyanin and ascorbic acid contents in raspberries, blackberries, red currants, gooseberries and Cornelian cherries. Food Chem 102:777-783. https:// doi.org/10.1016/j.foodchem.2006.06.021

60. Kostecka M, Szot I, Czernecki T, Szot P (2017) Vitamin C content of new ecotypes of cornelian cherry (Cornus mas L.) determined by various analytical methods. Acta Sci Pol Hortorum Cultus 16:53-61. https://doi.org/10.24326/asphc.2017.4.6

61. Aghdam MS, Dokhanieh AY, Hassanpour H, Rezapour Fard J (2013) Enhancement of antioxidant capacity of cornelian cherry (Cornus mas) fruit by postharvest calcium treatment. Sci Hortic (Amsterdam) 161:160-164. https://doi.org/10.1016/j.scien ta.2013.07.006

62. Hassanpour H, Yousef H, Jafar H, Mohammad A (2011) Antioxidant capacity and phytochemical properties of cornelian cherry (Cornus mas L.) genotypes in Iran. Sci Hortic (Amsterdam) 129:459-463. https://doi.org/10.1016/j.scienta.2011.04.017

63. Abbasi NA, Zafar L, Khan H, Qureshi AA (2013) Effects of naphthalene acetic acid and calcium chloride application on nutrient uptake, growth, yield and post harvest performance of tomato fruit. Pak J Bot 45:1581-1587

64. Forman V, Haladová M, Grančai D, Ficková M (2015) Antiproliferative activities of water infusions from leaves of five Cornus L. species. Molecules 20:22546-22552. https://doi.org/10.3390/ molecules201219786

65. Forman V, Haladová M, Grančai D (2015) Quantification of some secondary metabolites in selected Cornaceae species/ Stanovenie vybraných sekundárnych metabolitov v niektorých druhoch čel'ade Cornaceae. Acta Fac Pharm Univ Comenianae 62:8-11. https://doi.org/10.1515/afpuc-2015-0008

66. Celep E, Aydin A, Kirmizibekmez H, Yesilada E (2013) Appraisal of in vitro and in vivo antioxidant activity potential of cornelian cherry leaves. Food Chem Toxicol 62:448-455. https ://doi.org/10.1016/j.fct.2013.09.001

67. Krivoruchko E (2014) Carboxylic acids from Cornus mas. Chem Nat Compd 50:112-113. https://doi.org/10.1007/s1060 0-014-0879-y

68. Popović BM, Štajner D, Slavko K, Sandra B (2012) Antioxidant capacity of cornelian cherry (Cornus mas L.)-comparison between permanganate reducing antioxidant capacity and other antioxidant methods. Food Chem 134:734-741. https://doi. org/10.1016/j.foodchem.2012.02.170

69. Miláčková I, Meščanová M, Ševčíková V, Mučaji P (2017) Water leaves extracts of Cornus mas and Cornus kousa as aldose reductase inhibitors: the potential therapeutic agents. Chem Pap 71:2335-2341. https://doi.org/10.1007/s11696-017-0227-3

70. Świerczewska A, Buchholz T, Melzig MF, Czerwińska ME (2018) In vitro $\alpha$-amylase and pancreatic lipase inhibitory activity of Cornus mas L. and Cornus alba L. fruit extracts. J Food Drug Anal. https://doi.org/10.1016/j.jfda.2018.06.005

71. Asgary S, Rafieian-Kopaei M, Adelnia A, Kazemi S, Shamsi F (2010) Comparing the effects of lovastatin and Cornus mas fruit on fibrinogen level in hypercholesterolic rabbits. ARYA Atheroscler J 6:1-5

72. Leskovac A, Joksic G, Jankovic T, Savikin K, Menkovic N (2007) Radioprotective properties of the phytochemically characterized extracts of Crataegus monogyna, Cornus mas and
Gentianella austriaca on human lymphocytes in vitro. Planta Med 73:1169-1175. https://doi.org/10.1055/s-2007-981586

73. Asgary S, Kelishadi R, Rafieian-Kopaei M, Najafi S, Najafi M, Sahebkar A (2013) Investigation of the lipid-modifying and antiinflammatory effects of Cornus mas L. supplementation on dyslipidemic children and adolescents. Pediatr Cardiol 34:17291735. https://doi.org/10.1007/s00246-013-0693-5

74. Rosenson RS, Wright RS, Farkouh M, Plutzky J (2012) Modulating peroxisome proliferator-activated receptors for therapeutic benefit? Biology, clinical experience, and future prospects. Am Heart J 164:672-680. https://doi.org/10.1016/j.ahj.2012.06.023

75. Tang W, Zeve D, Suh JM, Bosnakovski D, Kyba M, Hammer RE, Tallquist MD, Graff JM (2008) White fat progenitor cells reside in the adipose vasculature. Science (80-) 322:583-586. https:// doi.org/10.1126/science. 1156232

76. Jayaprakasam B, Olson LK, Schutzki RE, Tai MH, Nair MG (2006) Amelioration of obesity and glucose intolerance in highfat-fed C57BL/6 mice by anthocyanins and ursolic acid in cornelian cherry (Cornus mas). J Agric Food Chem 54:243-248. https ://doi.org/10.1021/jf0520342

77. Choi YH, Jin GY, Li GZ, Yan GH (2011) Cornuside suppresses lipopolysaccharide-induced inflammatory mediators by inhibiting nuclear factor-kappa B activation in RAW 264.7 macrophages. Biol Pharm Bull 34:959-966. https://doi.org/10.1248/ bpb.34.959

78. Jiang W-L, Chen X-G, Zhu H-B, Tian J-W (2009) Effect of cornuside on experimental sepsis. Planta Med 75:614-619. https:// doi.org/10.1055/s-0029-1185383

79. Piekarska J, Szczypka M, Kucharska AZ, Gorczykowski M (2018) Effects of iridoid-anthocyanin extract of Cornus mas L. on hematological parameters, population and proliferation of lymphocytes during experimental infection of mice with Trichinella spiralis. Exp Parasitol 188:58-64. https://doi. org/10.1016/j.exppara.2018.03.012

80. Szumny D, Sozański T, Kucharska AZ, Dziewiszek W, Piórecki N, Magdalan J, Chlebda-Sieragowska E, Kupczynski R, Szeląg A, Szumny A (2015) Application of cornelian cherry iridoidpolyphenolic fraction and loganic acid to reduce intraocular pressure. Evid Based Complement Altern Med 2015:1-8. https://doi. org/10.1155/2015/939402

81. Alavian SM, Banihabib N, Haghi ME, Panahi F (2014) Protective effect of Cornus mas fruits extract on serum biomarkers in CCl4-induced hepatotoxicity in male rats. Hepat Mon. https:// doi.org/10.5812/hepatmon. 10330

82. Šavikin K, Zdunić G, Janković T, Stanojković T, Juranić Z, Menković N (2009) In vitro cytotoxic and antioxidative activity of Cornus mas and Cotinus coggygria. Nat Prod Res 23:17311739. https://doi.org/10.1080/14786410802267650

83. Yousefi B, Abasi M, Abbasi MM, Jahanban-Esfahlan R (2015) Anti-proliferative properties of Cornus mass fruit in different human cancer cells. Asian Pac J Cancer Prev 16:5727-5731. https://doi.org/10.7314/APJCP.2015.16.14.5727

84. Da Ronch F, Caudullo G, Houston Durrant T, de Rigo D (2016) Cornus mas in Europe: distribution, habitat, usage and threats. In: San-Miguel-Ayanz J, de Rigo D, Caudullo G, Houston Durrant T, Mauri A (eds) European atlas of forest tree species. Publication Office of the European Union, Luxembourg, pp 82-83

85. Yarılgaç T, Kadim H, Ozturk B (2019) Role of maturity stages and modified-atmosphere packaging on the quality attributes of cornelian cherry fruits (Cornus mas L.) throughout shelf life. J Sci Food Agric 99:421-428. https://doi.org/10.1002/jsfa.9203

86. Mohebbi S, Mostofi Y, Zamani Z, Najafi F (2015) Influence of modified atmosphere packaging on storability and postharvest quality of Cornelian cherry (Cornus mas L.) fruits. Not Sci Biol 7:116-122. https://doi.org/10.15835/nsb.7.1.9397 
87. Tesevic V, Nikicevic N, Milosavljevic S, Bajic D, Vajs V, Vuckovic I, Vujisic L, Djordjevic I, Stankovic M, Velickovic M (2009) Characterization of volatile compounds of "Drenja", an alcoholic beverage obtained from the fruits of Cornelian cherry. J Serbian Chem Soc 74:117-128. https://doi.org/10.2298/JSC0902117T

88. Sokół-Łętowska A, Kucharska AZ, Wińska K, Szumny A, Nawirska-Olszańska A, Mizgier P, Wyspiańska D (2014) Composition and antioxidant activity of red fruit liqueurs. Food Chem 157:533-539. https://doi.org/10.1016/j.foodchem.2014.02.083

89. Dragoni S, Gee J, Bennett R, Valoti M, Sgaragli G (2006) Red wine alcohol promotes quercetin absorption and directs its metabolism towards isorhamnetin and tamarixetin in rat intestine in vitro. Br J Pharmacol 147:765-771. https://doi.org/10.1038/ sj.bjp.0706662

90. Jakobek L, Matić P (2019) Non-covalent dietary fiber-polyphenol interactions and their influence on polyphenol bioaccessibility. Trends Food Sci Technol 83:235-247. https://doi. org/10.1016/j.tifs.2018.11.024

91. Xu L, Cheng J-R, Liu X-M, Zhu M-J (2019) Effect of microencapsulated process on stability of mulberry polyphenol and oxidation property of dried minced pork slices during heat processing and storage. LWT 100:62-68. https://doi.org/10.1016/j. lwt.2018.10.025

92. Bohn T, McDougall GJ, Alegría A, Alminger M, Arrigoni E, Aura A-M, Brito C, Cilla A, El SN, Karakaya S, Martínez-Cuesta MC, Santos CN (2015) Mind the gap-deficits in our knowledge of aspects impacting the bioavailability of phytochemicals and their metabolites - a position paper focusing on carotenoids and polyphenols. Mol Nutr Food Res 59:1307-1323. https://doi. org/10.1002/mnfr.201400745

93. Howard LR, Castrodale C, Brownmiller C, Mauromoustakos A (2010) Jam processing and storage effects on blueberry polyphenolics and antioxidant capacity. J Agric Food Chem 58:40224029. https://doi.org/10.1021/jf902850h

94. Schmidt BM, Erdman JW, Lila MA (2006) Effects of food processing on blueberry antiproliferation and antioxidant activity. J Food Sci 70:s389-s394. https://doi. org/10.1111/j.1365-2621.2005.tb11461.x

95. Palonen P, Weber C (2019) Horticulturae Fruit color stability, anthocyanin content, and shelf life were not correlated with ethylene production rate in five primocane raspberry genotypes. Sci Hortic (Amsterdam) 247:9-16. https://doi.org/10.1016/j.scien ta.2018.11.088

96. Barat A, Ozcan T (2018) Growth of probiotic bacteria and characteristics of fermented milk containing fruit matrices. Int J Dairy Technol 71:120-129. https://doi.org/10.1111/1471-0307.12391

97. Czyżowska A, Kucharska AZ, Nowak A, Sokół-Łętowska A, Motyl I, Piórecki N (2017) Suitability of the probiotic lactic acid bacteria strains as the starter cultures in unripe cornelian cherry (Cornus mas L.) fermentation. J Food Sci Technol 54:29362946. https://doi.org/10.1007/s13197-017-2732-3

98. Ivanova M, Petkova N, Balabanova T, Vlaseva R (2018) Food design of dairy desserts with encapsulated cornelian cherry, chokeberry and blackberry juices. Ann Univ Dunarea Jos Galati Fascicle VI Food Technol 42:137-146

99. Kucharska AZ, Kowalczyk K, Nawirska-Olszańska A, SokółŁętowska A (2010) Effect on cokeberry, strawberry, and raspberry added to Cornelian cherry puree on its physical and chemical composition. Żywność Nauk Technol Jakość 4:95-106

100. Tresserra-Rimbau A, Lamuela-Raventos RM, Moreno JJ (2018) Polyphenols, food and pharma. Current knowledge and directions for future research. Biochem Pharmacol 156:186-195. https:// doi.org/10.1016/j.bcp.2018.07.050

101. Cerit İ, Şenkaya S, Tulukoğlu B, Kurtuluş M, Seçilmişoğlu ÜR, Demirkol O (2016) Enrichemnt of functional properties of white chocolates with cornelian cherry, spinach and pollen powders.
Gida J Food 41:311-316. https://doi.org/10.15237/gida.GD160 29

102. Salejda AM, Kucharska AZ, Krasnowska G (2018) Effect of Cornelian cherry (Cornus mas L.) juice on selected quality properties of beef burgers. J Food Qual 2018:1-8. https://doi. org/10.1155/2018/1563651

103. Cakmakci S, Tosun M (2010) Characteristics of mulberry pekmez with cornelian cherry. Int J Food Prop 13:713-722. https ://doi.org/10.1080/10942910902804459

104. Kawa-Rygielska J, Adamenko K, Kucharska AZ, Piórecki N (2018) Bioactive compounds in cornelian cherry vinegars. Molecules. https://doi.org/10.3390/molecules23020379

105. Jaćimović V, Božović Đ (2017) Evaluation of cornelian cherry (Cornus mas L.) varieties and selections under the conditions of Gornje Polimlje region. Voćarstvo 51:81-86

106. Zhang Y, Zhang Y (2007) Study on reduction of acrylamide in fried bread sticks by addition of antioxidant of bamboo leaves and extract of green tea. Asia Pac J Clin Nutr 16:131-136. https ://doi.org/10.6133/apjen.2007.16.s1.25

107. Świeca M, Sęczyk Ł, Gawlik-Dziki U, Dziki D (2014) Bread enriched with quinoa leaves-the influence of protein-phenolics interactions on the nutritional and antioxidant quality. Food Chem 162:54-62. https://doi.org/10.1016/j.foodc hem.2014.04.044

108. Kolniak-Ostek J, Oszmiański J, Wojdyło A (2013) Effect of apple leaves addition on physicochemical properties of cloudy beverages. Ind Crops Prod 44:413-420. https://doi.org/10.1016/j.inder op.2012.12.003

109. Vanajakshi V, Vijayendra SVN, Varadaraj MC, Venkateswaran G, Agrawal R (2015) Optimization of a probiotic beverage based on Moringa leaves and beetroot. LWT Food Sci Technol 63:12681273. https://doi.org/10.1016/j.lwt.2015.04.023

110. Combet E, Gray SR (2019) Nutrient-nutrient interactions: competition, bioavailability, mechanism and function in health and diseases. Proc Nutr Soc 78:1-3. https://doi.org/10.1017/S0029 665118002732

111. Muros JJ, Sánchez-Muñoz C, Hoyos J, Zabala M (2019) Nutritional intake and body composition changes in a UCI World Tour cycling team during the Tour of Spain. Eur J Sport Sci 19:86-94. https://doi.org/10.1080/17461391.2018.1497088

112. Sanchez A, Mejia A, Sanchez J, Runte E, Brown-Fraser S, Bivens RL (2019) Diets with customary levels of fat from plant origin may reverse coronary artery disease. Med Hypotheses 122:103105. https://doi.org/10.1016/j.mehy.2018.10.027

113. Rezaeiamiri E, Bahramsoltani R, Rahimi R (2019) Plant-derived natural agents as dietary supplements for the regulation of glycosylated hemoglobin: a review of clinical trials. Clin Nutr. https:// doi.org/10.1016/j.clnu.2019.02.006

114. Liu B, Yan T, Xiao J, Wang X (2018) $\alpha$-Glucosidase inhibitors and antioxidants from root bark of Morus alba. Chin Herb Med 10:331-335. https://doi.org/10.1016/j.chmed.2018.02.004

115. Yimam M, Jiao P, Hong M, Brownell L, Kim Hyun-Jin, Lee Y-C, Jia Q (2018) Repeated dose 28-day oral toxicity study of a botanical composition composed of Morus alba and Acacia catechu in rats. Regul Toxicol Pharmacol 94:115-123. https:// doi.org/10.1016/j.yrtph.2018.01.024

116. Przeor M, Flaczyk E (2016) Antioxidant properties of paratha type flat bread enriched with white mulberry leaf extract. Indian J Tradit Knowl 15:237-244

117. Kobus-Cisowska J, Flaczyk E, Rudzińska M, Kmiecik D (2014) Antioxidant properties of extracts from Ginkgo biloba leaves in meatballs. Meat Sci 97:174-180. https://doi.org/10.1016/j.meats ci.2014.01.011

118. Walkowiak A, Ledziński Ł, Zapadka M, Kupcewicz B (2019) Detection of adulterants in dietary supplements with Ginkgo biloba extract by attenuated total reflectance Fourier transform 
infrared spectroscopy and multivariate methods PLS-DA and PCA. Spectrochim Acta Part A Mol Biomol Spectrosc 208:222228. https://doi.org/10.1016/j.saa.2018.10.008

119. Dorman DC, Côté LM, Buck WB (1992) Effects of an extract of Gingko biloba on bromethalin-induced cerebral lipid peroxidation and edema in rats. Am J Vet Res 53:138-142

120. Spencer JPE (2010) The impact of fruit flavonoids on memory and cognition. Br J Nutr 104:S40-S47. https://doi.org/10.1017/ S0007114510003934

121. Choudhary D, Bhattacharyya S, Bose S (2017) Efficacy and safety of Ashwagandha (Withania somnifera (L.) Dunal) root extract in improving memory and cognitive functions. J Diet Suppl 14:599-612

Publisher's Note Springer Nature remains neutral with regard to jurisdictional claims in published maps and institutional affiliations. 